Sang-Hoon Park

Kwang-won Lee

Tae-Ju Oh

Carl E. Misch

Jeffrey Shotwell

Hom-Lay Wang

\title{
Effect of absorbable membranes on sandwich bone augmentation
}

\author{
Authors' affiliations: \\ Sang-Hoon Park, School of Dentistry, University of \\ Maryland, Baltimore, MD, USA; Formerly School of \\ Dentistry, University of Michigan, Ann Arbor, MI, \\ USA \\ Kwang-won Lee, Periodontics, School of Dentistry, \\ Indiana University, Indianapolis, IN, USA \\ Tae-Ju Oh, Carl E. Misch, Hom-Lay Wang, \\ Department of Periodontics and Oral Medicine, \\ School of Dentistry, University of Michigan, Ann \\ Arbor, MI, USA \\ Jeffrey Shotwell, Department of Prosthodontics, \\ School of Dentistry, University of Michigan, Ann \\ Arbor, MI, USA
}

\section{Correspondence to:}

Sang-Hoon Park

Assistant Professor

School of Dentistry

University of Maryland

650 West Baltimore, Baltimore, MD 2 I 20 I

Tel.: 4438279248

Fax: 4IO 7067201

e-mail: sbpark@umich.edu

Key words: absorbable membrane, acellular dermal matrix, guided bone regeneration, mucogingival pouch flap, sandwich bone augmentation

\section{Abstract \\ Objectives: This study was conducted to evaluate the effect of barrier membranes on sandwich bone augmentation (SBA) for the treatment of implant dehiscence defects. Material and methods: Twenty-six implant-associated buccal dehiscence defects in 22 patients were treated according to the SBA concept - mineralized human cancellous allograft (inner layer), mineralized human cortical allograft (outer layer) and coverage with barrier membrane. The defects were randomly assigned to the bovine collagen membrane (BME) group; acellular dermal matrix (ADM) group; and no membrane group. \\ Measurements at baseline and 6 months re-entry included defect height (DH: from smooth- rough junction to the most apical part of the defect), defect width (DW: at the widest part of the defect), and horizontal defect depth (HDD: at three locations - smooth-rough junction, middle, and most apical portion of the defect). All measurements were taken from a reference stent. Statistical analyses were performed for comparison of intra- and inter- group comparisons.}

Results: All implants placed were successfully osseointegrated. $\mathrm{DH}$ at baseline for three groups were not significantly different $(P=0.858)$. Mean $\% \mathrm{DH}$ reductions for ADM, BME, and control groups at 6 months were $73.9 \pm 17.6 \%, 68.1 \pm 30.1 \%$, and $63.6 \pm 23.9 \%$, respectively, with no significant difference among the groups $(P=0.686)$. Mean horizontal bone gain, however, was significantly greater for membrane groups (1.7 $\mathrm{mm}$ for ADM, $1.6 \mathrm{~mm}$ for BME) compared with control group (1 mm) $(P=0.044)$. Implant exposure resulted in significant reduction in total height gain $(79.1 \pm 14.3 \%$ vs. $57 \pm 23.5 \%$, $P=0.021$ )

Conclusions: Within the limit of this study, it is concluded that SBA technique achieved predictable clinical outcomes. The addition of absorbable membranes enhanced bone gain in thickness compared with membrane-treated sites.

Simultaneous and staged guided bone regeneration (GBR) has gained its acceptance as an integral part of implant dentistry in augmenting a resorbed alveolar ridge. Retrospective and prospective long-term studies on survival rates of post-loaded implants survival rates in regenerated bone showed that: (I) survival rates of implants in regenerated bone are as high as those reported in native bone; (2) annual radiographic crestal bone loss of implants in regenerated bone is comparable with that in native bone; (3) simultaneous augmentation around exposed implant threads exhibited comparable results with staged bone augmentation (Buser et al. I996; 
Fugazzotto I997, 2005; Fiorellini et al. I998; Lorenzoni et al. I998, 2002; Nevins et al. I998; Cordioli et al. I999; Simion et al. 200I; Zitzmann et al. 200I; Hammerle et al. 2002; Christensen et al. 2003; Blanco et al. 2005).

Simultaneous GBR, in particular, became of a great interest as it could reduce treatment time by up to 6 months. Animal and human clinical studies have shown that predictable outcome with GBR depends upon several pre-requisites: wound stabilization via primary stability of the implant and absence of micro-movement of the membrane; space creation and maintenance; prevention of undesirable soft tissue cells; and sufficiently long-healing period (Dahlin et al. I989, I99I, I995; Palmer et al. I994; Hermann \& Buser I996; von Arx \& Kurt I999). Local host factors, such as defect height (DH), defect angle, defect width (DW), arch location, timing of implant placement, and defect morphology, have also been shown to influence GBR outcome (Gelb I993; Zitzmann et al. I997, 200I; Vanden Bogaerde 2004; Blanco et al. 2005; Moses et al. 2005). According to the studies described above, non-space making buccal dehiscence defects, commonly encountered in sites edentulous for more than 6 months, have been considered to be one of the most challenging defects.

In order to provide prolonged space maintenance and wound stabilization in nonspace making defects such as buccal dehiscence defects, Wang et al. (2004) has recently introduced the sandwich bone augmentation (SBA) technique. In SBA technique, autogenous bone or fast-resorbing allograft is laid under the second layer of slow-resorbing allograft or xenograft to enhance vital bone-to-implant contact via 'creeping substitution' of the inner layer during the early wound healing period (Goldberg \& Stevenson I987; Lyford et al. 2003). In addition, the second cortical layer provides mechanical support for prolonged space maintenance via 'reverse creeping substitution.'

Material selection has also been shown to influence the outcome of bone augmentation. Use of an absorbable membrane in combination with a bone filler showed comparable regenerative outcome as a non-resorbable membrane with a bone graft (Gelb I993; Lundgren et al. I994;
Zitzmann et al. I997, 200I; Mellonig et al. I998a, I998b; Carpio et al. 2000). Bovine collagen membranes (BME), in particular, have shown successful barrier function in animal and human studies (al-Arrayed et al. I995; Zitzmann et al. I997; Hockers et al. I999; Oh et al. 2003; Moses et al. 2005). They offer many advantages including minimized micromovement from early tissue integration (Sevor et al. I993), reduced infection, chemotactic function for PDL cells and osteoblasts (Postlethwaite et al. I978; Marinucci et al. 200I; Takata et al. 200Ia, 200Ib; Wang et al. 2002), early wound stabilization (Machtei et al. I994), hemostatic properties (Stein et al. I985), and no need of second surgery for membrane retrieval. However, due to a short-lasting nature and lack of resistance to collagenolytic enzymes, a citric acid/formaldehyde-treated BME (BioMend Extend ${ }^{\mathrm{TM}}$, Zimmer Dental Inc., Carlsbad, CA, USA) was introduced to improve its barrier function up to I6I 8 weeks. Oh et al. (2003), in an in vivo animal model, showed that the highly cross-linked BME had significantly higher linear bone fill (BF) and bone-implant contact (BIC) around peri-implant dehiscence defects, compared with a regular BME (BioGide ${ }^{\mathbb{B}}$, Osteohealth, Shirley, NY, USA) and control without a membrane. In general, collagen membranes have shown comparable outcomes with the non-resorbable ePTFE membrane in bone regeneration (Sevor et al. I993; Zitzmann et al. I997, 200I; Carpio et al. 2000).

Literatures have demonstrated that membrane exposure may occur in 40$60 \%$ in case of simultaneous GBR (Becker et al. I994; Gher et al. I994; Augthun et al. 1995; Zitzmann et al. I997). Early disruption of the wound healing from membrane/implant exposure can jeopardize bone regeneration by up to $80 \%$ (Jovanovic et al. I992; Lekholm et al. I993, I996; Becker et al. I994; Lang et al. I994; Nowzari \& Slots I995; Lorenzoni et al. I998; Machtei 200I; Tawil et al. 200I; Moses et al. 2005). Premature exposure of membranes led to early retrieval of membrane (Selvig et al. I992; Tempro \& Nalbandian I993; Simion et al. I994a, I994b; De Sanctis et al. I996), early degradation of absorbable membrane by bacterial collagenase (Zitzmann et al. I997), subsequent loss of bone graft, discontinuity between the graft and recipient bed (Donos 2002a, 2002b), and retraction of unattached flap with further exposure.

Recently, acellular dermal matrix (ADM, AlloDerm ${ }^{\circledR}$; BioHorizon, Birmingham, AL, USA), a bioabsorbable human skin allograft, has gained a popularity as a barrier membrane for GBR as it offers several advantages: ( $\mathrm{I}$ ) it is biocompatible and safe material; (2) primary closure may not be critical (Fowler et al. 2000a, 200ob); (3) no infection occurs upon exposure (Novaes \& Souza 200I; Novaes et al. 2002); (4) it acts like autograft thus esthetic and predictable; (5) it enhances gingival thickness by incorporating into the host tissue like autograft (Batista et al. 200I; Henderson et al. 2001; Harris 2002); and (6) it provides adequate barrier function lasting longer than 2 months (Owens \& Yukna 200I). ADM has shown great success in socket preservation (Fowler et al. 200ob; Griffin et al. 2004; Luczyszyn et al. 2005) and in reconstruction of minor defects with immediately placed implants (Fowler et al. 2000a, 200ob; Novaes et al. 2002). However, randomized controlled human clinical trials are not available showing its efficacy as a GBR membrane. Furthermore, no human regenerative studies have investigated the amount and pattern of bone thickness gain (TG) through simultaneous GBR.

Therefore, the purpose of this single examiner masked randomized-controlled study was to investigate the effect of two absorbable membranes (ADM, AlloDerm ${ }^{B}$; and a highly cross-linked BME, BioMend Extend $^{\mathrm{TM}}$ ) on SBA in augmenting non-space making implant-associated buccal dehiscence defects.

\section{Material and methods}

A total of 23 patients, older than I 8 years and systemically healthy, were included in the study. All recruited participants required single tooth replacement(s) with a dental implant associated with insufficient horizontal bone width. All sites had been edentulous for longer than 6 months. All subjects completed initial phase of periodontal therapy, if needed, and demonstrated good oral hygiene. Any medical contraindications for implant surgery were 
excluded from the study. In addition, heavy smokers with more than Io cigarettes per day were excluded. All study participants read, understood, and signed the informed consent form. The use of human subjects in this study was reviewed and approved by the Health Science Institutional Review Board (IRB) of the University of Michigan.

\section{Pre-surgical preparation}

For the assessment of ridge defects, all subjects were screened with clinical exam (i.e., bone sounding) and radiographic exam, including periapical, panoramic, and tomographic views, using a radiographic guide. A surgical template was fabricated from the master cast by a certified prosthodontist (J. S.). Oral hygiene instruction (OHI) and a thorough periodontal prophylaxis were given 3 weeks before the stage I surgery. OHI was repeated at each follow-up appointment, and prophylaxis was again performed at 3 months post-implantation.

\section{Surgical procedures}

Twenty-seven implants with implant-associated buccal dehiscence defects were randomized, by picking a code from a brown bag, into three groups: ADM (nine), BME (nine), and no membrane (nine). The examiner (K. W. L.) was blinded of the groups throughout the study.

Patients rinsed with 0.12\% chlorohexidine for $60 \mathrm{~s}$ before the surgery, and $2 \mathrm{~g}$ amoxicillin or $600 \mathrm{mg}$ clindamycin (if allergic to penicillin) was orally administered immediately before surgery. For flap reflection, the mucogingival pouch flap design was employed (Park \& Wang 2005). Initial crestal incision was made $2 \mathrm{~mm}$ lingual to the mid-crest away from the defect. Vertical releasing incisions were made along the mucogingival junction, leaving I-I.5 mm papilla intact if possible. Full-thickness mucoperiosteal flap was reflected. Before implant placement, thorough debridement was carried out. A MTX-surfaced implant (Tapered Screw-Vent ${ }^{\mathbb{B}}$, Zimmer Dental Inc., Carlsbad, CA, USA) was placed following the guidance of the surgical template. The smooth-rough junction was $0.5 \mathrm{~mm}$ below the crest (Fig. Ib). A masked examiner measured the dehiscence defect dimension using a pre-fabricated reference template (Fig. I). The site receiving bone grafting was decorticated using $\mathrm{I} / 2$ round bur to facilitate migration of bone marrow cells into the recipient bed. Defects were then augmented according to SBA techni-
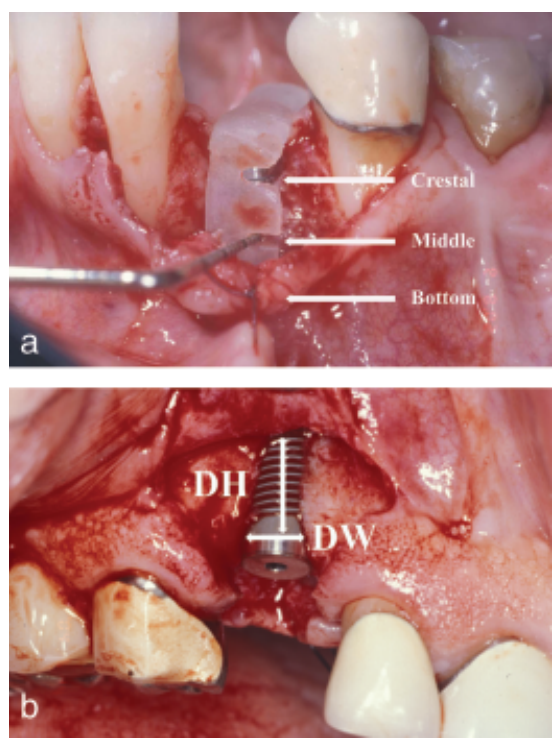

Fig. I. Defect measurements. (a) Thickness measured at three points of the defect, crestal, middle, bottom. (b) DH, defect height; DW, defect width. (c) Thickness measured at three points of the defect, crestal, middle, bottom. (d) $\mathrm{DH}$; DW.
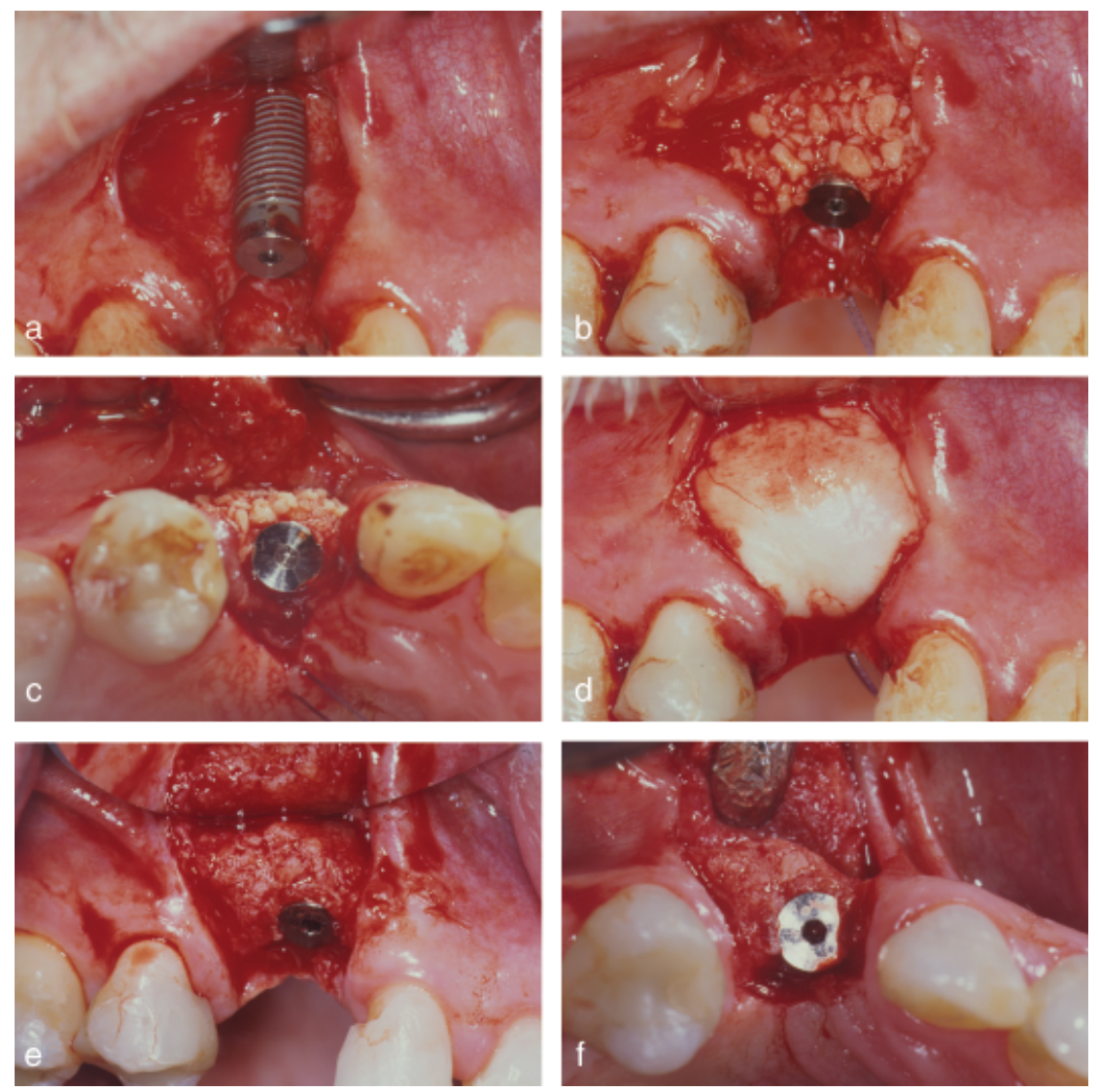

Fig. 2. Buccal dehiscence, graft placement, 6 months clinical re-entry for acellular dermal matrix. (a) Buccal dehiscence. (b) Buccal view of Puros ${ }^{10}$ grafting in two layers. (c) Occlusal view of Puros in two layers. (d) AlloDerm-GBR. ${ }^{\circledR}$ placement. (e) Buccal view of 6 months re-entry (f) Occlusal view of 6 months re-entry. 
Patient were instructed to rinse with warm salt water for the first 2 weeks, followed by 0.12\% chlorohexidine gluconate mouthrinse (Peridex ${ }^{\circledR}$, Zila Inc., Pheonix, AZ, USA) twice daily for I month. Sutures were removed 2 weeks post-surgery. Postoperative evaluations were provided at 2 weeks, I month, 3, and 6 months.

Stage II surgery was performed 6 months after implant placement, using the same flap design as stage I surgery (Fig. 2e and f). Same clinical parameters were recorded at the stage I surgery were taken. Cases with threads exposed were re-grafted with Puros $^{\mathbb{B}}$ cancellous and BME with additional 6 months healing time before appropriate implant supported prosthetic treatment was provided.

\section{Clinical parameters}

The unit of analysis was the implant. Clinical measurements at the time of stage I surgery, included DHDH (from smoothrough junction to most apical point of the defect), DW (widest portion of the defect), and horizontal defect depths (HDD: at three locations - smooth-rough junction, middle, most apical part of the defect) (Fig. I). HDDs were measured using a I $\mathrm{mm}$ thick pre-fabricated acrylic reference stent attached to the implant-healing cap. Grooves were made at three different locations on the buccal portion of the stent once dehiscence was observed. The stent allowed repeated measurements of bone thickness at baseline and 6 months $4 \mathrm{~mm}$ away from the implant surface, and also ensured a standardized initial graft thickness of $3 \mathrm{~mm}$ (Fig. I). One masked examiner performed all measurements using a North Carolina Probe. Calibration was conducted before, during, and after the study to ensure adequate intra-examiner reliability. Overall, intra-examainer reproducibility as evaluated by intra-class correlation coefficient, was 0.97 for the blinded examiner (K. W. L.). The measurements were repeated at 6 months re-entry. Membrane/implant exposure was also recorded. Based on the clinical measurement data, the following parameters were evaluated:

\footnotetext{
$\%$ defect height reduction

$=\underline{\text { Defect height at baseline }- \text { Defect height at } 6 \text { months }}$

$=\frac{\text { Defect height at baseline }}{\times}$

$\times 100 \%$
}

Percent BF was calculated using hemisphere factor of $\mathrm{I} / 4$ pi (Zitzmann et al.
I997, I999, 2001):

Surface area of exposed implant

$=$ length $\times$ width $\times$ I $/ 4$ pi $(=0.785)$

$\%$ bone fill

$=\underline{\text { Exposed surface area at baseline }- \text { Exposed surface area at re-entry }}$ $\times 100 \%$ Exposed surface area at baseline

\section{Statistical analysis}

Statistical analysis was performed using SPSS Statistical package (SPSS $^{\circledR}$ I 3.0 for windows $^{\circledR}$, SPSS Inc., 2000. Troy, NY, USA). Defect measurements of each group at baseline and 6 months were compared using univariate one-way ANOVA and pair-wise Bonferroni's correction methods. Paired samples $t$-test was used to compare intra-group pre- and post-treatment $\mathrm{DH}$ comparison (Table 2). Independent samples $t$-test was performed to compare between sites with membrane exposure and sites without membrane exposure at 6 months. The data were presented as mean \pm SD, and the significance level was set at $P<0.05$.
Twenty-seven defect sites in 23 patients were included for the study and treated via simultaneous bone grafting with or without a barrier membrane (ADM or BME). The mean age of the patients subjects was ranging from 28 to $7 \mathrm{I}$, and there were Io males and 13 females. All patients except for one were non-smokers. With one defect site, one patient from no membrane group was excluded due to an unforeseen health issue, resulting that 26 implants were included for statistical analysis. Twenty-one $3.7 \mathrm{~mm}$ and five $4.7 \mathrm{~mm}$ diameter implants were used. Eleven were ro $\mathrm{mm}$ and I 5 were $13 \mathrm{~mm}$ in length. Ten implants were placed in the maxilla while 16 implants were placed in the mandible. Throughout the research, all patients maintained good oral hygiene with no visible plaque and signs of inflammation or infection.

All implants were successfully osseointegrated at 6 months. Baseline $\mathrm{DH}$ and area showed no significant difference among the three groups (Table I; $P>0.05$ ). Intra-group

\section{Results}

Table 1. Comparison of GBR outcomes among treatment groups

\begin{tabular}{|c|c|c|c|}
\hline Parameters & Group & Mean $\pm S D$ & $P$-value \\
\hline \multicolumn{4}{|l|}{ Defect height $(\mathrm{mm})$} \\
\hline \multirow[t]{3}{*}{ Baseline } & ADM & $6.58 \pm 2.79$ & \\
\hline & BME & $6.23 \pm 3.51$ & 0.858 \\
\hline & Control & $5.81 \pm 1.86$ & \\
\hline \multirow[t]{3}{*}{6 months } & ADM & $1.47 \pm 1.19$ & \\
\hline & BME & $1.42 \pm 1.35$ & 0.501 \\
\hline & Control & $2.21 \pm 1.96$ & \\
\hline \multicolumn{4}{|l|}{ Defect width $(\mathrm{mm})$} \\
\hline \multirow[t]{3}{*}{ Baseline } & ADM & $3.48 \pm 1$ & \\
\hline & BME & $3.49 \pm 0.73$ & 0.326 \\
\hline & Control & $3.32 \pm 0.8$ & \\
\hline \multirow[t]{3}{*}{6 months } & ADM & $1.61 \pm 1.6$ & \\
\hline & BME & $1.5 \pm 1.8$ & 0.893 \\
\hline & Control & $1.94 \pm 1.18$ & \\
\hline \multicolumn{4}{|l|}{ Defect area $\left(\mathrm{mm}^{2}\right)$} \\
\hline \multirow[t]{3}{*}{ Baseline } & ADM & $18.93 \pm 11.8$ & \\
\hline & BME & $18.3 \pm 12.16$ & 0.561 \\
\hline & Control & $13.82 \pm 5.43$ & \\
\hline \multirow[t]{3}{*}{6 months } & ADM & $2.96 \pm 3.53$ & \\
\hline & BME & $3.25 \pm 4.23$ & 0.777 \\
\hline & Control & $4.51 \pm 6.15$ & \\
\hline \multirow[t]{3}{*}{ Horizontal bone gain $(\mathrm{mm})$} & ADM & $1.74 \pm 0.38^{*}$ & $0.039(* 0.044)$ \\
\hline & BME & $1.57 \pm 0.76$ & \\
\hline & Control & $1.02 \pm 0.47^{*}$ & \\
\hline \multirow[t]{3}{*}{$\%$ reduction defect height } & ADM & $73.89 \pm 17.58$ & 0.686 \\
\hline & BME & $68.14 \pm 30.1$ & \\
\hline & Control & $63.56 \pm 23.88$ & \\
\hline \multirow[t]{3}{*}{$\%$ bone fill } & ADM & $78.28 \pm 21.8$ & 0.917 \\
\hline & BME & $78.73 \pm 28.89$ & \\
\hline & Control & $73.8 \pm 29$ & \\
\hline
\end{tabular}

*Pairwise Bonferroni's multiple comparison showing a significant difference at $P<0.05$.

$A D M$, acellular dermal matrix; BME, bovine collagen membrane; GBR, guided bone regeneration. 
comparison showed clinically significant bone height gain at 6 months compared with baseline (Table 2; $P<0.05$ ). Within each treatment group, no significant correlations existed between pre- and post-treatment bone height gain. At 6 months, no significant difference was found among three groups in percent defect height reduction (DHR) and percent bone fill (BF) (Table I; $P=0.686$ and $P=0.9$ I 7 ). ADM, BME, and control group resulted in DHR of $73.9 \pm$ $\mathrm{I} 7.6 \%, 68 . \mathrm{I} \pm 30 . \mathrm{\%} \%$, and $63.6 \pm 23.9 \%$, respectively. $\mathrm{BF}$ for $\mathrm{ADM}, \mathrm{BME}$, and control group were $78.3 \pm 21.8 \%, 78.7 \pm 28.9 \%$, and $73.8 \pm 29 \%$, respectively. Mean TG in membrane groups, however, was greater compared with the control group with statistical significance (Tables I \& 3; I.7 $\mathrm{mm}$ vs. I $\mathrm{mm} ; P=0.012)$. The mean gains in thickness were in the following order: $\mathrm{ADM}(\mathrm{I} .7 \mathrm{~mm}) \sim \operatorname{BME}(\mathrm{I} .6 \mathrm{~mm})>$ control (I mm), with a statistically significant difference between ADM and control group $(P=0.044)$. When TG was compared by locations within each defect (crest, middle, bottom), they were significantly different among the locations: bottom $>$ middle $>$ crest (data not shown).

Comparison of graft thickness loss (or bone resorption) showed that membrane groups sustained initial graft thickness better at 6-month re-entry (Table 4). ADM and BME have undergone $1.26 \pm 0.38$ and $\mathrm{I} .43 \pm 0.76 \mathrm{~mm}$ of horizontal thickness loss while control group has undergone I.98 $\pm 0.47 \mathrm{~mm}$, significantly more than ADM group $(P=0.044)$.

Nine sites experienced either membrane or implant exposure (Table 5). There was significant difference in both reduction in defect height $(\mathrm{RDH})$ and $\mathrm{BF}$ between exposed and non-exposed sites, with the difference more than $20 \%$. Within group comparison, significant difference between exposed and non-exposed sites was found only in BME group $(P=0.005$ for $\mathrm{RDL}$; $P=0.043$ for $\mathrm{BF})$. No significant difference was seen between exposed and non-exposed cases when TG was compared in all groups $(P=0.400)$.

\section{Discussion}

This one-examiner blinded randomized controlled study was to examine the effect of two barrier membranes, human dermal matrix and $\mathrm{BME}$, for the simultaneous guided bone regeneration on implant dehiscence defects in humans. All treatment groups in our study were grafted using the SBA technique (Wang et al. 2004). This technique takes advantage of 'creeping substitution' properties of cancellous allograft for enhanced early mechanical strength and enhanced vital BIC while prolonged me- chanical support for space maintenance is achieved via 'reverser creeping substitution' of cortical allograft (Goldberg \& Stevenson 1987; Bauer \& Muschler 2000; Lyford et al. 2003; Wang et al. 2004).

Primary outcome variables were percent $\mathrm{RDH}$, percent BF, and TG. All sites selected in the study were edentulous for greater than 6 months before the implant

Table 2. Intragroup comparison between pre- and post-treatment bone height gain

\begin{tabular}{lllll}
\hline Groups & Parameters & Mean \pm SD $(\mathrm{mm})$ & $P$-value & Correlation \\
\hline ADM & Pre-treatment defect height & $6.58 \pm 2.79$ & $0.002^{*}$ & 0.492 \\
& Post-treatment defect height & $1.47 \pm 1.19$ & & \\
BME & Pre-treatment defect height & $6.23 \pm 3.51$ & $0.008^{*}$ & 0.392 \\
& Post-treatment defect height & $1.42 \pm 1.35$ & \multirow{2}{*}{$0.001^{*}$} & \multirow{2}{*}{0.215} \\
Control & Pre-treatment defect height & $5.81 \pm 1.86$ & & \\
& Post-treatment defect height & $2.21 \pm 1.96$ & &
\end{tabular}

*Paired samples $t$-test showing significance at $P<0.05$.

ADM, acellular dermal matrix; BME, bovine collagen membrane.

Table 3. Comparison between membrane groups and no membrane group

\begin{tabular}{llrll} 
Parameters & Groups & $N$ & Mean & $P$-value \\
\hline \% defect height reduction & Membranes & 18 & $71.02 \pm 24.09$ & 0.472 \\
& No membranes & 8 & $63.56 \pm 23.88$ & \\
\% bone fill & Membranes & 18 & $78.51 \pm 24.83$ & 0.676 \\
& No membranes & 8 & $73.8 \pm 29$ & \\
Horizontal bone gain $(\mathrm{mm})$ & Membranes & 18 & $1.66 \pm 0.59$ & 0.012 \\
& No membranes & 8 & $1.02 \pm 0.467$ & \\
\hline
\end{tabular}

Table 4. Graft thickness loss (or bone resorption) at 6 month re-entry

\begin{tabular}{lllll}
\hline \multicolumn{5}{c}{ Initial horizontal } \\
bone thickness (mm)at 6 months (mean \pm SD) & \multicolumn{1}{c}{ loss (mean \pm SD) } \\
\hline ADM & 3 & $1.74 \pm 0.38^{*}$ & $1.26 \pm 0.38^{*}$ & \\
BME & 3 & $1.57 \pm 0.76$ & $1.43 \pm 0.76$ & $0.039\left({ }^{*} 0.044\right)$ \\
Control3 & $1.02 \pm 0.47^{*}$ & $1.98 \pm 0.47^{*}$ & \\
\hline *Bonferroni multiple comparison showing a significant difference. & \\
ADM, acellular dermal matrix; BME, bovine collagen membrane. \\
\hline
\end{tabular}

Table 5. GBR outcome comparison between implant exposure vs. no exposure

\begin{tabular}{|c|c|c|c|c|c|}
\hline \multirow[t]{2}{*}{ Exposure } & \multicolumn{4}{|c|}{ Mean \pm SD } & \multirow[t]{2}{*}{$P$-values } \\
\hline & & & W & W/O & \\
\hline Mean \% defect height reduction & W & $\mathrm{W} / \mathrm{O}$ & & & \\
\hline $\operatorname{ADM}(n=9)$ & 2 & 7 & $54.85 \pm 3.18$ & $79.33 \pm 15.96$ & 0.101 \\
\hline $\operatorname{BME}(n=9)$ & 5 & 4 & $51.12 \pm 29.68$ & $89.43 \pm 12.4$ & 0.005 \\
\hline Control $(n=8)$ & 2 & 6 & $73.75 \pm 12.37$ & $70.6 \pm 8.62$ & 0.834 \\
\hline All groups $(n=26)$ & & & $56.98 \pm 23.53$ & $79.13 \pm 14.31$ & 0.021 \\
\hline \multicolumn{6}{|l|}{ Mean \% bone fill } \\
\hline $\operatorname{ADM}(n=9)$ & & & $54.89 \pm 3.19$ & $84.97 \pm 19.93$ & 0.083 \\
\hline BME $(n=9)$ & & & $65.42 \pm 33.26$ & $95.37 \pm 9.26$ & 0.043 \\
\hline Control $(n=8)$ & & & $82.49 \pm 14.84$ & $83.49 \pm 13.37$ & 0.954 \\
\hline All groups $(n=26)$ & & & $66.87 \pm 26.08$ & $87.11 \pm 15.76$ & 0.039 \\
\hline \multicolumn{6}{|l|}{ Mean thickness gain $(\mathrm{mm})$} \\
\hline $\operatorname{ADM}(n=9)$ & & & $1.5 \pm 0.24$ & $1.81 \pm 0.4$ & 0.486 \\
\hline $\mathrm{BME}(n=9)$ & & & $1.3 \pm 0.85$ & $1.92 \pm 0.52$ & 0.107 \\
\hline Control $(n=8)$ & & & $1.33 \pm 0.71$ & $1.03 \pm 0.3$ & 0.517 \\
\hline All groups $(n=26)$ & & & $1.35 \pm 0.66$ & $1.59 \pm 0.54$ & 0.400 \\
\hline
\end{tabular}

ADM, acellular dermal matrix; BME, bovine collagen membrane; GBR, guided bone regeneration. 
placement. Six months re-entries revealed that all bone regenerated showed score of 4 (very dense - resistant to pressure of probe) or 5 (density comparable with healthy bone) on Mattout density scale (Mattout et al. I995). Membrane groups showed slightly greater $\mathrm{RDH}$ and $\mathrm{BF}$ compared with no membrane group. Mean percent BF found in our study $(78.5 \pm 24.8 \%)$ was equivalent to that in long-term delayed implant placement group (LTDIP - more than 6 months after tooth extraction) in a retrospective study by Zitzmann et al. (I999). In their study, LTDIP showed significantly less percent $\mathrm{BF}(92 \pm 24 \%$ for maxilla and $72 \pm 37.6 \%$ for mandible) compared with the immediate implant placement $(96 \pm 9.8 \%$ for maxilla; $8 \mathrm{I} \pm$ $34.5 \%$ for mandible) and the short-term delayed implant placement groups -6 weeks to 6 months after tooth extraction (Ioo \pm o $\%$ for maxilla; $86 \pm 25.8 \%$ for mandible). It was speculated that lower mean percent BF in LTDIP group was attributed to (I) the absence of well-vascularized spongious matrix, (2) the fact that most of LTDIP showed one-wall or no-wall defects, which does not support the space, and (3) denser bone quality (Zitzmann et al. I999). In our study, more implants were placed in the mandible, which could have skewed mean percent BF closer to $72 \%$ BF found in Zitzmann's study. Both our study and Zitzmann's study showed greater bone regeneration compared with the results from the randomized control trial by Carpio et al. (2000). Low defect reduction $139.6 \%$ for collagen membrane and $45.9 \%$ for ePTFE) in their study might have resulted from high membrane/implant exposure rate $147.8 \%$ for collagen membrane; $45.8 \%$ for ePTFE). Another clinical study reported DHR and percent $\mathrm{BF}$ (75.2 \pm I $7.99 \%$ and $87.6 \pm$ I I.48\%, respectively) in similar types of defects (Nemcovsky \& Artzi 2002). The study used MTX surfaced implants same as our study. Greater gain in $\mathrm{DH}$, compare with DHR observed in our study, might be explained by the fact that all implants placed, in their late-implant placement group, were in the maxillary arch.

Six-month re-entry showed no significant difference in mean percent DHR and mean percent $\mathrm{BF}$ among treatment groups. This suggests that SBA without barrier could support bone regeneration around the implant. Furthermore, carefully re- flected periosteum might have provided barrier function and served as a reservoir for nutrition and growth factors for bone regeneration (Linde et al. I993). Jovanovic et al. (I995) supported osteoconductive properties of the periosteum as membrane alone group exhibited equivalent or greater height gain in augmenting buccal dehiscence defects in animals, compared with the standard ePTFE membrane. In a similar animal study, Mellonig et al. (I998a, I 998b) further speculated that use of a nonrigid membrane without any bone graft may in fact hinder bone regeneration as they lack the regenerative potential residing in the periosteum. On the contrary, others suggested that the presence or absence of the periosteum does not influence bone regeneration (Melcher I969, I976; Melcher \& Accursi I97I; Reid et al. I98I). They speculated that a thin layer of osteogenic cambium with progenitor cells in the periosteum were damaged upon flap elevation. Weng et al. (2000) further supported the low osteogenic potential of the periosteum, in a non-human primate model, by histological observations that the newly regenerated bone exclusively deposited on the old bone. No bone formation was observed on the flap side. Therefore, they concluded that periosteum did not contribute to the new bone formation. On the contrary, our study showed that the control group gained comparable height as the membrane groups, with no difference noted in the clinical appearance of the regenerated hard tissue among all three groups. This finding agrees with potential barrier function of periosteum.

Although no difference was seen in $\mathrm{DH}$ and area reduction among all treatment groups, use of membranes gained I.5 to two times thicker buccal bone compared with control $(P=0.012 ; \mathrm{I} .7 \pm 0.6 \mathrm{~mm}$ for membrane groups; I $\pm 0.5 \mathrm{~mm}$ for control). It can be speculated that, in spite of its barrier function, periosteum alone might not be rigid enough to stabilize the graft against movable overlying flap, muscle attachment, and shallow vestibules. Bone thickness gained in our study has clinical relevance in implant therapy. Although exposed threads were not associated with mucosal problems and progressive bone resorption in a 5-year retrospective study (Lekholm et al. I996), stable vertical dimension supported by adequate thickness of bone is considered essential for appropriate esthetics. Spray et al. (2000), from analysis of 306I implants, found that a mean facial bone thickness of $1.7 \mathrm{~mm}$ at stage I surgery in non-regenerated bone was associated with high survival rate at uncovering surgery. When initial bone thickness approached I.8$2 \mathrm{~mm}$, the vertical bone level remained stable. In the absence of membrane exposure, simultaneous GBR with SBA technique in our study achieved I.8-1.9 $\mathrm{mm}$ at uncovering surgery. The difference between these two studies was that Spray et al. (2000) measured 'initial facial bone thickness' at stage I surgery while the comparable thickness reported in our study was 'final facial bone thickness' measured at stage II surgery. This indicates that facial bone thickness achieved via GBR in our study might remain stable for longer duration than that found in Spray's article. However, no long-term prospective studies have evaluated the stability of facial bone level in relationship with the bone thickness gained via simultaneous GBR. Furthermore, according to previous studies, the outcomes of GBR procedures, in terms of alveolar dimensions, undergo to dimensional modifications also after 6 months (Simion et al. 200I; Chiapasco et al. 2004). The evaluation period of the present study could be not sufficient to determine the entity of the graft remodelling.

Loss of horizontal bone thickness, or bone resorption, was further calculated at 6 months re-entry (Table 4). Bone resorption was greatest for control group followed by BME and ADM groups with a significant difference between $\mathrm{ADM}$ and control group $(P=0.044)$. Bone resorption reached $43 \%$ of initial graft thickness with membrane compared with $66 \%$ without membrane. Animal and human studies have shown that presence of a membrane led to a less bone resorption for block graft (Rasmusson et al. I999; Antoun et al. 200I; Donos et al. 2002a, 2002b, 2002c). However, greater loss could be expected in our study since less graft stability is expected during wound healing due to the nature of the particulate graft used. Standardization of the initial graft thickness, although attempted in our study, could not be guaranteed as graft shape changes upon flap closure. Other factors such as flap 
tension, depth of vestibule, muscle attachment, and compression after surgery, may significantly influence the initial graft thickness. Furthermore, upon membrane or implant exposure, premature graft loss through the incompletely closed wound can be significant and immeasurable. Therefore, horizontal thickness loss in our study does not purely represent bone resorption process.

When the effect of early implant exposure on bone regeneration was considered, different patterns were observed in the different treatment groups. Exposure resulted in significantly reduced bone regeneration down to $57 \%$ DHR in our study. This compromised bone regeneration has been suggested to be attributed to $(\mathrm{I})$ the bacterial contamination and subsequent inflammation of sub- and peri-membranous soft tissue (Mombelli et al. I993; Schmid et al. I994; Nowzari \& Slots I995), and (2) early degradation of collagen membrane by bacterial collagenases (Donos et al. 2002d). Donos et al. (2002d) further reported that premature exposure can lead to extensive resorption of bone graft and discontinuity between graft and the host bone. It was reported that the extent of the detrimental effect from early exposure of membrane is much more significant in GBR as opposed to GTR (Machtei 200I). In case of simultaneous GBR, non-exposed group yielded almost six times more new bone formation compared with exposed group. The amount of bone regeneration reported by literature ranged from $2 \mathrm{I} \%$ to $76.4 \%$ in exposure groups (Lekholm et al. I993; Zitzmann et al. I997; Lorenzoni et al. I998; Machtei 200I; Moses et al. 2005). In our study, BMEs upon exposure underwent early degradation within 3-4 weeks after surgery is considered to be critical membrane retention period for accommodating uninterrupted osteogenic cell migrations and mitotic activity (Bunyaratavej \& Wang 200I). Subsequent loss of particulated graft through unattached flap, along with shrinkage of overlying tissue, might have significantly affected the outcome. This negative impact, however, appeared to be diminished in ADM group. Four of six cases in ADM group that experienced premature exposure of ADM were epithelialized over I month period without implant exposure. None of them underwent degradation or infection upon exposure as seen in other studies (Novaes \& Souza 200I; Novaes et al. 2002). This might have been due to a polarized matrix nature, providing scaffold for both epithelial cell migration and angiogenic cells (Livesey et al. I995; Cummings et al. 2005). Future studies are needed to validate this speculation.

In conclusion, SBA technique, with or without use of membrane, showed predictable outcomes in guided bone augmentation in this study. Both absorbable membrane-treated groups and no membrane group were capable of resolving dehiscence DH to a similar extent. The main effect of membrane, however, was the greater gain in bone thickness compared with sites without a barrier.

Acknowledgements: This work was partially supported by the University of Michigan Periodontal Graduate

Student Research Fund as well as a gift grant from Zimmer Dental Inc. The materials used for this study were kindly donated by the Zimmer Dental Inc., and BioHorizon Inc. Clinical implication: This study showed that sandwich bone augmentation is a predictable guided bone augmentation technique for gaining bone height as well as width. The usage of absorbable membranes enhanced clinical outcomes.

\begin{abstract}
要旨
目的：本研究は、インプラントの裂開型欠 損の治療に用いる、サンドイッチ式骨増生 術（SBA）に対するバリヤー・メンブレンの 効果を評価した。

材料と方法: 患者 22 名においてインプラ ントに関連する頖側裂開型久損 26 箇所を、 石灰化したヒト海綿骨同種移植片(内層)、 石灰化したヒト皮質骨同種移植片（外層） とバリヤー・メンブレンによる被覆という SBAの概念に基づいて治療した。欠損部は、 牛コラーグン・メンブレン群（BME）、無 細胞性皮膚マトリクス群 (ADM)およびメ ンブレン無使用郡に無作為に割り付けた。 ベースライン時と 6 ケ月後の二次手術時に、 欠損の高さ (DH:滑沢面と粗面の境界から 久損の最も根尖側までの距離)、久損の幅 (DW:欠損の最も幅が広い部分) および水 平的欠損の寸法 (HDD:滑沢面と粗面の境 界、久損の中央部と最も根尖側の 3 箇所の 寸法）を測定した。すべての測定は、ステ ントを基準にして行った。統計学的分析に よって、群内および群間の比較を行った。 結果 : 全てのインプラントは、成功裏に骨 性結合を達成した。ベースライン時の久損 の高径には 3 群間に有意差はなかった （p=0.858）。ADM 群、BME 群および対照 群の平均欠損高径の減少率は 6 ケ月後の時 点で、各々 $73.9 \pm 17.6 \% 、 68.1 \pm 30.1 \%$ お び 63.6土23.9\%であり、群間に有意差はな かった $(\mathrm{p}=0.686)$ 。水平的骨の獲得量の平 均は、メンブレン使用の 2 群 (ADM 群が $1.7 \mathrm{~mm} 、 \mathrm{BME}$ 群が $1.6 \mathrm{~mm}$ ) が対照群 (1.0mm) よりも有意に優れていた。（ p $=0.044)$ 。インプラントの露出は、総高径 の獲得量に有意な减少をもたらした $(79.1$ $\pm 14.3 \%$ 対 $57.0 \pm 23.5 \% 、 \mathrm{p}=0.021)$ 。

結論：本研究の制約内において、骨増生步 ンドイッチ法は予知性のある臨床的結果を もたらしたと結論される。吸収性メンブレ ンの使用は、メンブレン使用部位と比較し て、骨の厚みの獲得量が増加した。
\end{abstract}

\section{References}

al-Arrayed, F., Adam, S., Moran, J. \& Dowell, P. (I995) Clinical trial of cross-linked human type I collagen as a barrier material in surgical periodontal treatment. Journal of Clinical Periodontol 22: 37 I-379.

Antoun, H., Sitbon, J.M., Martinez, H. \& Missika, P. (200I) A prospective randomized study comparing two techniques of bone augmentation: onlay graft alone or associated with a membrane. Clinical Oral Implants Research I2: 632-639. von Arx, T. \& Kurt, B. (I999) Implant placement and simultaneous ridge augmentation using autogenous bone and a micro titanium mesh: a prospective clinical study with 20 implants. Clinical Oral Implants Research Io: 24-33.

Augthun, M., Yildirim, M., Spiekermann, H. \& Biesterfeld, S. (I995) Healing of bone defects in combination with immediate implants using the membrane technique. International Journal of Oral and Maxillofacial Implants Io: 42 I-428.
Batista, E.L. Jr, Batista, F.C. \& Novaes, A.B. Jr (200I) Management of soft tissue ridge deformities with acellular dermal matrix. Clinical approach and outcome after 6 months of treatment. Journal of Periodontology 72: 265-273.

Bauer, T.W. \& Muschler, G.F. (2000) Bone graft materials. An overview of the basic science. Clinical Orthopedic Related Research 371: I0-27.

Becker, W., Dahlin, C., Becker, B.E., Lekholm, U., van Steenberghe, D., Higuchi, K. \& Kultje, C. 
(1994) The use of e-PTFE barrier membranes for bone promotion around titanium implants placed into extraction sockets: a prospective multicenter study. International Journal of Oral and Maxillofacial Implants 9: 3 I-40.

Blanco, J., Alonso, A. \& Sanz, M. (2005) Long-term results and survival rate of implants treated with guided bone regeneration: a 5 -year case series prospective study. Clinical Oral Implants Research I6: 294-30I.

Bunyaratavej, P. \& Wang, H.L. (200I) Collagen membranes: a review. Journal of Periodontology 72: $215-229$.

Buser, D., Dula, K., Lang N, P. \& Nyman, S. (I996) Long-term stability of osseointegrated implants in bone regenerated with the membrane technique. 5 -year results of a prospective study with I2 implants. Clinical Oral Implants Research 7: I75-I83.

Carpio, L., Loza, J., Lynch, S. \& Genco, R. (2000) Guided bone regeneration around endosseous implants with anorganic bovine bone mineral. A randomized controlled trial comparing bioabsorbable versus non-resorbable barriers. Journal of Periodontology 71: 1743-1749.

Chiapasco, M., Romeo, E., Casentini, P. \& Rimondini, L. (2004) Alveolar distraction osteogenesis vs. vertical guided bone regeneration for the correction of vertically deficient edentulous ridges: a I-3-year prospective study on humans. Clinical Oral Implants Research I 5: 82-95.

Christensen, D.K., Karoussis, I.K., Joss, A., Hammerle, C.H. \& Lang, N.P. (2003) Simultaneous or staged installation with guided bone augmentation of transmucosal titanium implants. A 3-year prospective cohort study. Clinical Oral Implants Research I4: 680-686.

Cordioli, G., Majzoub, Z. \& Riachi, F. (I999) Postloading behavior of regenerated tissues in GBR-treated implant sites. International Journal of Periodontics and Restorative Dentistry I9: 44-55.

Cummings, L.C., Kaldahl, W.B. \& Allen, E.P. (2005) Histologic evaluation of autogenous connective tissue and acellular dermal matrix grafts in humans. Journal of Periodontology 76: 178-I86.

Dahlin, C., Andersson, L. \& Linde, A. (I99I) Bone augmentation at fenestrated implants by an osteopromotive membrane technique. A controlled clinical study. Clinical Oral Implants Research 2: I59-I65.

Dahlin, C., Lekholm, U., Becker, W., Becker, B., Higuchi, K., Callens, A. \& van Steenberghe, D. (1995) Treatment of fenestration and dehiscence bone defects around oral implants using the guided tissue regeneration technique: a prospective multicenter study. International Journal of Oral and Maxillofacial Implants Io: 3I 2-3 I 8.

Dahlin, C., Sennerby, L., Lekholm, U., Linde, A. \& Nyman, S. (1989) Generation of new bone around titanium implants using a membrane technique: an experimental study in rabbits. International Journal of Oral and Maxillofacial Implants 4 : I9-25.

De Sanctis, M., Zucchelli, G. \& Clauser, C. (I996) Bacterial colonization of bioabsorbable barrier material and periodontal regeneration. Journal of Periodontology 67: I I 93-I 200.
Donos, N., Kostopoulos, L. \& Karring, T. (2002a) Augmentation of the mandible with GTR and onlay cortical bone grafting: An experimental study in the rat. Clinical Oral Implants Research I3: $175-184$.

Donos, N., Kostopoulos, L. \& Karring, T. (2002b) Alveolar ridge augmentation by combining autogenous mandibular bone grafts and non-resorbable membranes: an experimental study in the rat. Clinical Oral Implants Research I3: I 85-I9I.

Donos, N., Kostopoulos, L. \& Karring, T. (2002 C) Augmentation of the rat jaw with autogeneic cortico-cancellous bone grafts and guided tissue regeneration. Clinical Oral Implants Research I3: 192-202.

Donos, N., Kostopoulos, L. \& Karring, T. (2002d) Alveolar ridge augmentation using a resorbable copolymer membrane and autogenous bone grafts. An experimental study in the rat. Clinical Oral Implants Research I3: 203-2 I3.

Fiorellini, J.P., Engebretson, S.P., Donath, K. \& Weber, H.P. (1998) Guided bone regeneration utilizing expanded polytetrafluoroethylene membranes in combination with submerged and nonsubmerged dental in plants in beagle dogs. Journal of Periodontology 69: 528-535.

Fowler, E.B., Breault, L.G. \& Rebitski, G. (2000a) Ridge preservation utilizing an acellular dermal allograft and demineralized freeze-dried bone allograft: part I. A report of 2 cases. Journal of Periodontology 71: I353-I359.

Fowler, E.B., Breault, L.G. \& Rebitski, G. (200ob) Ridge preservation utilizing an acellular dermal allograft and demineralized freeze-dried bone allograft: part II. Immediate endosseous implant placement. Journal of Periodontology 71: I360-I364.

Fugazzotto, P.A. (I997) Success and failure rates of osseointegrated implants in function in regenerated bone for 6 to $5 \mathrm{I}$ months: a preliminary report. International Journal of Oral and Maxillofacial Implants 12: 17-24.

Fugazzotto, P.A. (2005) Success and failure rates of osseointegrated implants in function in regenerated bone for 72 to I 33 months. International Journal of Oral and Maxillofacial Implants 20: 77-83.

Gelb, D.A. (I993) Immediate implant surgery: three-year retrospective evaluation of 50 consecutive cases. International Journal of Oral and Maxillofacial Implants 8: 388-399.

Gher, M.E., Quintero, G., Assad, D., Monaco, E. \& Richardson, A.C. (I994) Bone grafting and guided bone regeneration for immediate dental implants in humans. Journal of Periodontology 65: 88 I-89I.

Goldberg, V.M. \& Stevenson, S. (I987) Natural history of autografts and allografts. Clinical Orthopedic Related Research 225: 7-I6.

Griffin, T.J., Cheung, W.S. \& Hirayama, H. (2004) Hard and soft tissue augmentation in implant therapy using acellular dermal matrix. International Journal of Periodontics and Restorative Dentistry 24: 352-36I.

Hammerle, C.H., Jung, R.E. \& Feloutzis, A. (2002) A systematic review of the survival of implants in bone sites augmented with barrier membranes (guided bone regeneration) in partially edentulous patients. Journal of Clinical Periodontology 29 $(\mathrm{s} 3): 226-23 \mathrm{I}$
Harris, R.J. (2002) Cellular dermal matrix used for root coverage: I8-month follow-up observation. International Journal of Periodontics and Restorative Dentistry 22: I 5 6-I63.

Henderson, R.D., Greenwell, H., Drisko, C., Regennitter, F.J., Lamb, J.W., Mehlbauer, M.J., Goldsmith, L.J. \& Rebitski, G. (200I) Predictable multiple site root coverage using an acellular dermal matrix allograft. Journal of Periodontology 72: $571-582$.

Hermann, J.S. \& Buser, D. (1996) Guided bone regeneration for dental implants. Current Opinion in Periodontology 3: I 68-177.

Hockers, T., Abensur, D., Valentini, P., Legrand, R. \& Hammerle, C.H. (1999) The combined use of bioresorbable membranes and xenografts or autografts in the treatment of bone defects around implants. A study in beagle dogs. Clinical Oral Implants Research 10: 487-498.

Jovanovic, S.A., Schenk, R.K., Orsini, M. \& Kenney, E.B. (I995) Supracrestai bone formation around dental implants: an experimental dog study. International Journal of Oral and Maxillofacial Implants I0: 23-3I.

Jovanovic, S.A., Spiekermann, H. \& Richter, E.J. (I992) Bone regeneration around titanium dental implants in dehisced defect sites: a clinical study. International Journal of Oral and Maxillofacial Implants 7: 233-245.

Lang, N.P., Hammerle, C.H., Bragger, U., Lehmann, B. \& Nyman, S.R. (I994) Guided tissue regeneration in jawbone defects prior to implant placement. Clinical Oral Implants Research 5: 92-97.

Lekholm, U., Becker, W., Dahlin, C., Becker, B., Donath, K. \& Morrison, E. (I993) The role of early versus late removal of GTAM membranes on bone formation at oral implants placed into immediate extraction sockets. An experimental study in dogs. Clinical Oral Implants Research 4 : I 2 I-I 29.

Lekholm, U., Sennerby, L., Roos, J. \& Becker, W. (I996) Soft tissue and marginal bone conditions at osseointegrated implants that have exposed threads: a 5-year retrospective study. International Journal of Oral and Maxillofac Implants II: 599-604.

Linde, A., Thoren, C., Dahlin, C. \& Sandberg, E. (1993) Creation of new bone by an osteopromotive membrane technique: an experimental study in rats. Journal of Oral and Maxillofacial Surgery 5I: $892-897$.

Livesey, S.A., Herndon, D.N., Hollyoak, M.A., Atkinson, Y.H. \& Nag, A. (1995) Transplanted acellular allograft dermal matrix. Potential as a template for the reconstruction of viable dermis. Transplantation 6o: I-9.

Lorenzoni, M., Pertl, C., Keil, C. \& Wegscheider, W.A. (I998) Treatment of peri-implant defects with guided bone regeneration: a comparative clinical study with various membranes and bone grafts. International Journal of Oral and Maxillofacial implants I3: 639-646.

Lorenzoni, M., Pertl, C., Polansky, R.A., Jakse, N. \& Wegscheider, W.A. (2002) Evaluation of implants placed with barrier membranes. A retrospective follow-up study up to five years. Clinical Oral Implants Research I3: 274-280.

Luczyszyn, S.M., Papalexiou, V., Novaes, A.B Jr, Grisi, M.F., Souza, S.L. \& Taba, M. Jr (2005) 
Acellular dermal matrix and hydroxyapatite in prevention of ridge deformities after tooth extraction. Implant Dentistry I4: 176-I84.

Lundgren, D., Sennerby, L., Falk, H., Friberg, B. \& Nyman, S. (1994) The use of a new bioresorbable barrier for guided bone regeneration in connection with implant installation. Case reports. Clinical Oral Implants Research 5: 177-184.

Lyford, R.H., Mills, M.P., Knapp, C.I., Scheyer, E.T. \& Mellonig, J.T. (2003) Clinical evaluation of freeze-dried block allografts for alveolar ridge augmentation: a case series. International Journal of Periodontics and Restorative Dentistry 23: 4I7-425.

Machtei, E.E. (200I) The effect of membrane exposure on the outcome of regenerative procedures in humans: a meta-analysis. Journal of Periodontology 72: 5 I 2-5 I6.

Machtei, E.E., Cho, M.I., Dunford, R., Norderyd, J., Zambon, J.J. \& Genco, R.J. (I994) Clinical, microbiological, and histological factors which influence the success of regenerative periodontal therapy. Journal of Periodontology 65: I54-I6I.

Marinucci, L., Lilli, C., Baroni, T., Becchetti, E., Belcastro, S., Balducci, C. \& Locci, P. (200I) In vitro comparison of bioabsorbable and non-resorbable membranes in bone regeneration. Journal of Periodontology 72: 753-759.

Mattout, P., Nowzari, H. \& Mattout, C. (I995) Clinical evaluation of guided bone regeneration at exposed parts of branemark dental implants with and without bone allograft. Clinical Oral Implants Research 6: 189-195.

Melcher, A.H. (1969) Role of the periosteum in repair of wounds of the parietal bone of the rat. Archives of Oral Biology I4: I IoI-I IO9.

Melcher, A.H. (1976) On the repair potential of periodontal tissues. Journal of Periodontology 47: 256-260.

Melcher, A.H. \& Accursi, G.E. (I97I) Osteogenic capacity of periosteal and osteoperiosteal flaps elevated from the parietal bone of the rat. Archives of Oral Biology I6: 573-580.

Mellonig, J.T., Nevins, M. \& Sanchez, R. (I998a) Evaluation of a bioabsorbable physical barrier for guided bone regeneration. Part I. Material alone. International Journal of Periodontics and Restorative Dentistry I 8: I 39-I49.

Mellonig, J.T., Nevins, M. \& Sanchez, R. (I998b) Evaluation of a bioabsorbable physical barrier for guided bone regeneration. Part II. Material and a bone replacement graft. International Journal of Periodontics and Restorative Dentistry $\mathbf{1 8}$ : I29-I37.

Mombelli, A., Lang, N.P. \& Nyman, S. (I993) Isolation of periodontal species after guided tissue regeneration. Journal of Periodontology 64: I I 7 III75.

Moses, O., Pitaru, S., Artzi, Z. \& Nemcovsky, C.E. (2005) Healing of dehiscence-type defects in implants placed together with different barrier membranes: a comparative clinical study. Clinical Oral Implants Research I6: 2 I0-2 I9.

Nemcovsky, C.E. \& Artzi, Z. (2002) Comparative study of buccal dehiscence defects in immediate, delayed, and late maxillary implant placement with collagen membranes: clinical healing be- tween placement and second-stage surgery. Journal of Periodontology 73: 754-76I.

Nevins, M., Mellonig, J.T., Clem, D.S., Reiser, G.M. \& Buser, D.A. (I998) Implants in regenerated bone: long-term survival. International Journal of Periodontics and Restorative Dentistry $\mathbf{I} 8$ : $34-45$.

Novaes, A.B. Jr, Papalexiou, V., Luczyszyn, S.M., Muglia, V.A., Souza, S.L.S. \& Taba, M. Jr (2002) Immediate implant in extraction socket with acellular dermal matrix graft and bioactive glass: a case report. Implant Dentistry II: 343-348.

Novaes, A.B. \& Souza, S.L. (200I) Acellular dermal matrix graft as a membrane for guided bone regeneration: a case report. Implant Dentistry Iо: 192-I96.

Nowzari, H. \& Slots, J. (I995) Microbiologic and clinical study of polytetrafluoroethylene membranes for guided bone regeneration around implants. International Journal of Oral and Maxillofacial Implants ro: 67-73.

Oh, T.J., Meraw, S.J., Lee, E.J., Giannobile, W.V. \& Wang, H.L. (2003) Comparative analysis of collagen membranes for the treatment of implant dehiscence defects. Clinical Oral Implants Research I4: 80-90.

Owens, K.W. \& Yukna, R.A. (200I) Collagen membrane resorption in dogs: a comparative study. Implant Dentistry Io: 49-58.

Palmer, R.M., Floyd, P.D., Palmer, P.J., Smith, B.J., Johansson, C.B. \& Albrektsson, T. (I994) Healing of implant dehiscence defects with and without expanded polytetrafluoroethylene membranes: a controlled clinical and histological study. Clinical Oral Implants Research 5: 98-IO4.

Park, S.H. \& Wang, H.L. (2005) Mucogingival pouch flap (MPF) for sandwich bone augmentation. Implant Dentistry I4: 349-354.

Postlethwaite, A.E., Seyer, J.M. \& Kang, A.H. (I978) Chemotactic attraction of human fibroblasts to type I, II, and III collagens and collagenderived peptides. Proceedings of National Academy of Sciences USA 75: 87I-875.

Rasmusson, L., Meredith, N., Kahnberg, K.E. \& Sennerby, L. (I999) Effects of barrier membranes on bone resorption and implant stability in onlay bone grafts: An experimental study. Clinical Oral Implants Research Iо: 267-277.

Reid, C.A., McCarthy, J.G. \& Kolber, A.B. (I98I) A study of regeneration in parietal bone defects in rabbits. Plastic and Reconstructive Surgery $\mathbf{6}_{7}$ : 59I-596.

Schmid, J., Hammerle, C.H., Olah, A.J. \& Lang, N.P. (I994) Membrane permeability is unnecessary for guided generation of new bone. An experimental study in the rabbit. Clinical Oral Implants Research 5: I25-I30.

Selvig, K.A., Kersten, B.G., Chamberlain, A.D., Wikesjo, U.M. \& Nilveus, R.E. (I992) Regenerative surgery of intrabony periodontal defects using ePTFE barrier membranes: scanning electron microscopic evaluation of retrieved membranes versus clinical healing. Journal of Periodontology $\mathbf{6 3}$ : 974-978.

Sevor, J.J., Meffert, R.M. \& Cassingham, R.J. (I993) Regeneration of dehisced alveolar bone adjacent to endosseous dental implants utilizing a resorbable collagen membrane: clinical and histologic results. International Journal of Periodontics and Restorative Dentistry I3: 7 I-83.

Simion, M., Baldoni, M., Rossi, P. \& Zaffe, D. (r994a) A comparative study of the effectiveness of e-PTFE membranes with and without early exposure during the healing period. International Journal of Periodontics and Restorative Dentistry I4: I66-I80.

Simion, M., Dahlin, C., Trisi, P. \& Piattelli, A. (I994b) Qualitative and quantitative comparative study on different filling materials used in bone tissue regeneration: a controlled clinical study. International Journal of Periodontics and Restorative Dentistry I4: I $98-2$ I 5.

Simion, M., Jovanovic, S.A., Tinti, C. \& Benfenati, S.P. (200I) Long-term evaluation of osseointegrated implants inserted at the time or after vertical ridge augmentation. A retrospective study on 123 implants with I-5 year follow-up. Clinical Oral Implants Research I2: 35-45.

Spray, J.R., Black, C.G., Morris, H.F. \& Ochi, S. (2000) The influence of bone thickness on facial marginal bone response: stage I placement through stage 2 uncovering. Annals of Periodontology 5: I I 9 -I 28.

Stein, M.D., Salkin, L.M., Freedman, A.L. \& Glushko, V. (I985) Collagen sponge as a topical hemostatic agent in mucogingival surgery. Journal of Periodontology 56: 35-38.

Takata, T., Wang, H.L. \& Miyauchi, M. (200ra) Migration of osteoblastic cells on various guided bone regeneration membranes. Clinical Oral Implants Research I2: 332-338.

Takata, T., Wang, H.L. \& Miyauchi, M. (200Ib) Attachment, proliferation and differentiation of periodontal ligament cells on various guided tissue regeneration membranes. Journal of Periodontal Research 36: 322-327.

Tawil, G., El-Ghoule, G. \& Mawla, M. (200I) Clinical evaluation of a bilayered collagen membrane (Bio-Gide) supported by autografts in the treatment of bone defects around implants. International Journal of Oral and Maxillofacial Implants I6: 857-863.

Tempro, P.J. \& Nalbandian, J. (1993) Colonization of retrieved polytetrafluoroethylene membranes: morphological and microbiological observations. Journal of Periodontology 64: I62-I68.

Vanden Bogaerde, L. (2004) A proposal for the classification of bony defects adjacent to dental implants. International Journal of Periodontics and Restorative Dentistry 24: 264-27I.

Wang, H.L., Misch, C. \& Neiva, R.F. (2004) "Sandwich" bone augmentation technique: rationale and report of pilot cases. International Journal of Periodontics and Restorative Dentistry 24: 232-245.

Wang, H.L., Miyauchi, M. \& Takata, T. (2002) Initial attachment of osteoblasts to various guided bone regeneration membranes: an in vitro study. Journal of Periodontal Research 37: 340-344.

Weng, D., Hurzeler, M.B., Quinones, C.R., Ohlms, A. \& Caffesse, R.G. (2000) Contribution of the periosteum to bone formation in guided bone regeneration. A study in monkeys. Clinical Oral Implants Research II: 546-554. 
Park et al . Effect of absorbable membranes for sandwich bone augmentation

Zitzmann, N.U., Naef, R. \& Scharer, P. (I997) Resorbable versus nonresorbable membranes in combination with Bio-Oss for guided bone regeneration. International Journal of Oral and Maxillofacial Implants I2: 844-852.
Zitzmann, N.U., Scharer, P. \& Marinello, C.P. (1999) Factors influencing the success of GBR. Smoking, timing of implant placement, implant location, bone quality and provisional restoration. Journal of Clinical Periodontology 26: 673-682.
Zitzmann, N.U., Scharer, P. \& Marinello, C.P. (200I) Long-term results of implants treated with guided bone regeneration: a 5-year prospective study. International Journal of Oral and Maxillofacial Implants I6: 355-366. 